\title{
Gold and Greater Britain: Jevons, Trollope, and Settler Colonialism
}

\author{
PHILIP STEER
}

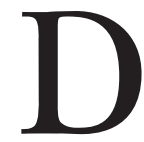
espite the current reframing of Victorian studies in transnational or global terms, the writing that emerged out of the borderless world of Britain and its settler colonies has yet to receive significant attention. When it is discussed, the settler colony is typically cast as the endpoint in a one-way flow of cultural "portability," in which metropolitan forms are deployed to affirm British values and to "disavow" the cultural and historical specificities of local conditions (Plotz 48). In contrast, imperial historiography has seen an energetic renewal of interest in the distinctive social, economic, and political linkages that bound what is variously called the "Britannic" world-system (Darwin 145), "British World" (Bridge and Fedorowich 3; Magee and Thompson xii), or "Anglo-World" (Belich 49). This body of work stresses that the rhetoric of racial and cultural commonality was integral to the development of the settler empire's material networks and underpinned a view of settlement as qualitatively different from other forms of imperialism. . "Transfers of things, thoughts, and

\footnotetext{
Abstract: The Australian gold rushes of the 1850 s provide an exemplary test case for exploring the impact of Greater Britain-the settler colonial empire-on the Victorian novel and political economy. British gold diggers' nomadism operated in seeming antithesis to the colonies' explosive growth, which posed a conceptual challenge both to political economy's stadial model of societal development and to liberal narratives of labor and land-narratives that underpinned concepts of individual character and civil society. Informed by colonial writing and the experience of gold fields, W. S. Jevons's Theory of Political Economy (1871) and Anthony Trollope's John Caldigate (1879) reimagine metropolitan space and subjectivity in settler-colonial terms, helping lay the ground for a deterritorialized, global British identity.

Philip STEer (P.Steer@massey.ac.nz) is Senior Lecturer in the School of English and Media Studies at Massey University. His work has appeared in Victorian Literature and Culture and Victorian Review, and in the collection Imagining Victorian Settler Homes: Antipodal Domestic Fiction (Pickering \& Chatto, 2014). He is currently completing a book on the transnational culture of Victorian settler colonialism.
} 
people, lubricated by shared language and culture, were easier within them than from without," James Belich observes, as "changes flowed more easily within the system, and were received more readily" (49). The political significance of language and sentiment ensures that the burden of theorizing the connections between Britain and its disparate zones of settlement lies with literary scholars as much as with economic historians:as Dror Wahrman points out in response to Belich, "If they cannot produce the remains of the veins and sinews of this global nineteenth-century multi-headed English-speaking hydra, then it probably never lived" (99). As Wahrman implies, those "veins and sinews" have not proved particularly obvious, despite several decades of postcolonialist attention to the culture of Victorian empire. Thus, of the three imperial events that shook Britain in the 1850s-the Indian Rebellion, the Crimea campaign, and the Australian gold rushes-the sensational discoveries at the antipodes have received the least critical attention, and for that reason provide an exemplary test case for exploring the settler "veins and sinews" of Victorian culture. At the time of the gold rushes, observers pointed to the "large . . Australian element . . gradually working itself into our current literature" (Fowler 1), but in this essay I argue that the most wide-reaching impact of the gold rushes on Victorian culture was not this brief flourishing of discussion about Australia. Rather, events at the antipodes played out more thoroughly in Victorian thinking through a network of mobile writers-most notably, Anthony Trollope and W. S. Jevons-who registered their colonial experiences as challenges to the liberal narratives of labor and land that underpinned early Victorian concepts of individual character and societal development. Such challenges to British society and identity, as well as the forms of political economy and the novel through which they were articulated, comprised the debatable common property of what C. W. Dilke influentially termed "Greater Britain" in his 1869 book of that title. ${ }^{3}$

Put broadly, I argue that the narrative dimension of Greater Britain can best be glimpsed in the traffic between political economy and the novel that occurred across the metropolis and the settler colony as part of the project to replicate Victorian society abroad. Accordingly, I begin my analysis several decades prior to the gold rushes, with the establishment of Australia as a case study in political economy in Edward Gibbon Wakefield's theory of "systematic" settler colonization (Hickford 61). Beginning with the publication of $A$ 
Letter from Sydney: The Principal Town of Australasia (1829), Wakefield advocated for numerous colonial projects on the basis that new, settler British societies could be reliably built upon the application of familiar Lockean and stadialist principles, which posited that culture and capitalism only emerged out of the civilizing activities of sedentary agricultural labor. Yet if character came from developing the land with labor, as Locke had taught economists to assume, what happened to a society whose wealth arrived at random from holes in the ground?

The colonial novel constitutes ground zero for the conceptual challenges that the gold rushes posed to those early Victorian orthodoxies of character development and nation formation. In Clara Morison: A Tale of South A ustralia During the Gold Fever (1854), written by Australian settler Catherine Helen Spence, the discovery of gold is figured as a clear threat to the social order and literary culture of the only Australian colony founded on Wakefield's principles of development. "If Australia should ever become a great nation," the poet and prospector R. H. Horne wrote only a few years later, "we, the pick-andshovel men, have dug out that nationality" (126). The simplicity of this equation between the labor of resource extraction and the formation of national identity belies the scale of the formal accommodations that Australia's gold-fueled boom demanded of the economic and literary principles informing the Victorian ideal of the settled society. These formal changes were prompted in particular by the seeming opposition between the primitive, nomadic behavior of British gold diggers and the explosive growth of the colonies' cities and economies. ${ }^{4}$ Such complexities and contradictions were placed dramatically on display in a popular account of the gold rushes, Land, Labour and Gold; or, Two Years in Victoria (1855) by British literary Jack-of-all-trades William Howitt. The new social vision emerging in the antipodes was first given theoretical shape in works of colonial political economy. Written in the gold colony of Victoria and in keeping with the ethos of the unsettled society out of which it emerged, W.E.Hearn's Plutology:or, The Theoryof the Efforts to Satisfy Human Wants(1864) proposed radically reorienting political economy away from production and toward a subject driven by "varied and insatiable desires" (21).

This essay traces the dissemination of these emergent ideas about character and nation into metropolitan writing. Informed by their Australian experiences, W. S. Jevons's The Theory of Political Economy (1871) and Anthony Trollope's John Caldigate (1879) both 
offer narratives of delocalized and desiring metropolitan individuals, the former through extending Hearn's insights into marginalist economic theory and the latter by grounding its protagonist's gentlemanly qualities in colonial conditions. Such material and intellectual exchanges were the means by which Greater Britain helped catalyze developments within Victorian culture: Australia is a waypoint in the transition to a consumer-driven economic model, and the related reconceptualization of British identity coheres across the empire's core and settler periphery. The settler colonial environment reveals and magnifies the global unconscious of metropolitan thought, with the gold rushes and the writing they generated reimagining the British subject as a deterritorialized citizen of the world.

Operating alongside and in conjunction with vast movements of the population and transfers of capital, Greater Britain's textual dimension is characterized by the formal complexities that arise from the clash of metropolitan and colonial concerns across discontinuous imperial spaces. These complexities can be readily glimpsed in the structure and preoccupations of William Howitt's Land, Labour, and Gold (1885), the decade's "most influential single work" on the gold rushes (Goodwin, "British" 406). Already established as a poet, journalist, and editor before he traveled to Melbourne in 1852, Howitt asserts a confident sense of the geographic and political distance between his British readership and his Australian subject matter: "I had no interest in the questions involved . . . and no purpose to serve but a patriotic one" (vii). However, this aloof metropolitan narrative perspective is immediately undermined by the work's epistolary form, through which Howitt recounts his peripatetic and enthusiastic search for colonial gold. As the narrative unfolds, it also testifies to the inseparability in Australia of literary and economic domains: Howitt primarily assesses the suitability of the colony and the aptitude of its colonists by its relative picturesqueness, yet his title specifically invokes the three factors of production-land, labor, and capital-that underpin classical political economy. Such global entanglements of form, materiality, and geography constitute a "cultural-political field" of the kind envisaged by Caroline Levine, in which "literary forms and social formations can be grasped as comparable and overlapping patternings operating on a common plane" ("Strategic" 626). According to Levine's formulation, works such as Howitt's constitute the literary dimension of Greater Britain by functioning as a complex 
interface operating on two levels: first, as enabling the "overlapping" between metropolitan and colonial spatial and social orders; and second, as a means of mediating between material flows (of migrants and bullion) and ideological systems (of political economy and aesthetics, and the novelistic forms employed to make sense of them). Shaped by hundreds of thousands of British migrants and millions of ounces of gold, the "common plane" of Victorian culture explored here extended beyond the borders of Britain to the antipodean limits of the settler empire and was characterized by an ongoing traffic between metropolitan cultural formations and the material conditions of the Australian discoveries.

The ready global movement of British authors and their texts across the empire further confirms that in any discussion of Greater Britain, problems of form are always also questions of mobility and circulation. Building on James Buzard's description of the Victorian novel as "auto-ethnographic," John Plotz has offered a "general description of transmissible culture in Victorian Greater Britain" (23) defined by a desire for the "pure asymmetry" of literary circulation (22). Here, a racialized distinction between metropolis and colony informs a model of portability as cultural export: "If in the best of times portability is the mechanism ensuring that British culture survives unaltered overseas, at the worst of times the process can also go into reverse, sending from the edges of empire to its core artifacts still freighted with foreign meaning" (22). Yet in the case of Greater Britain, the possibilities for exchange between British populations in the metropolis and those at the "edges of empire" require an alternative theory of portability as circulation, such as that offered by Isabel Hofmeyr's transnational history of John Bunyan's Pilgrim's Progress (1678), which stresses how "the material routes of circulation" produce novel "forms of publicness" on the periphery that in turn shaped Bunyan's reception in Britain (14). Hofmeyr's vision of imperial textuality as "a complex force field in which circuits of influence travel in more than one direction" (24) seems especially apt in light of a July 1852 account in Chambers's Edinburgh Journal. The piece describes a recent disturbance of the "solitude and silence" of the Scottish hills of Fife and Kinross due to "thousands of persons plying every kind of instrument upon them ... in search of gold, which they believed to be hidden in their recesses." The upheaval, reported to last three weeks, was triggered by a former resident who had been transported 
to Australia and had recently seen some of the ore produced at the diggings: "It at once struck him that he had seen abundance of the same material in his native hills. . . . This impression he conveyed in a letter to his mother, who, as a matter of course, afforded the information to all to whom she had an opportunity of communicating it" (“Gold-Seeking" 60). The convict's influential letter exemplifies the capacity for antipodean settler narratives to prove disproportionately effective in reconfiguring the very ground of metropolitan experience. Marking the completion of an imperial circuit of migration and information exchange that originated in Britain years earlier, the Fifeshire gold rush suggests the permeability of Victorian culture to the wider influence of Greater Britain, registered not through explicit representations of the colonies but in the broader reconceptualizing of metropolitan society in colonial terms.

\section{I.}

By the time Australia's first gold rush began in May 1851 at Bathurst, New South Wales, the continent's colonization had been understood for several decades as a laboratory experiment in political economy. Taking their impetus from John Locke's argument that it was the individual's labor in nature that jointly gave rise to private property and to political order, Scottish Enlightenment conjectural historians developed an elaborate narrative of society's pathway to civilization by way of four discrete stages, each defined by specific forms of territoriality, labor, and culture, and this developmental schema was in turn imported wholesale into early Victorian economics. As J. R. McCulloch maintained in his influential Principles of Political Economy (1825), the first step beyond savagery occurs with the adoption of hunting, yet such populations remain "like beasts of prey . . . thinly scattered over the surface of the countries which they occupy" (67). The second stage of development occurs with animal domestication and shepherding, yet it is the adoption of a sedentary mode of production that marks the true threshold of civilization:

The thirdand most decisive step in the progress of civilization. . . is made when the wandering tribes of hunters and shepherds renounce their migratory habits, and become agriculturists and manufacturers. It is then that man begins fully to avail himself of his productive powers. He then becomes laborious, and, by a necessary consequence, his wants are then, for the first time, fully supplied.(68) 
As McCulloch's emphasis on this final step suggests, the multiple social gradations charted by stadialist theory were frequently condensed into a spatialized opposition between two fundamental modes of production, "the hunter and shepherd relegated to vagrancy, the ploughman and merchant to sedentary civilization" (Pocock 212). As the basis for Edward Gibbon Wakefield's influential argument that nomadic "dispersion" was the greatest threat to the renewal of British settler colonization, this imagined threshold between nomadic and settled society gained a startling political importance beginning in the late $1820 \mathrm{~s}$.

From his first published account of his theory of "systematic" colonization, A Letterfrom Sydney, Wakefield and his acolytes in the Colonial Reform movement argued that the establishment of a settled British society at the antipodes depended on rethinking the spatial logic of political economy. ${ }^{5}$ First published anonymously in installments in the Morning Chronicle from August to October 1829, Letterfrom Sydneypurported to be the correspondence of a disgruntled member of the first generation of non-convict (free) settlers in Australia. ${ }^{6}$ His purchase of 20,000 acres had been premised on the fantasy of the colonial waste central to Lockean thought-that it is an underutilized, even uninhabited space that can only be truly possessed by sedentary labor-but Wakefield dispels that vision by presenting the sheer surplus of land as inimical to the imperial project. "The reason is plain," he maintains: "there are millions upon millions of acres, as fertile as mine, to be had for nothing; and, what is more, there are not people to take them," so that his particular estate has no economic value (103). The limitlessness of the land also threatens attempts to replicate the structure of British society by prompting the dissolution of class distinctions and the dispersal of the colonists: "There is no such class as a tenantry in this country, where every man, who has capital to cultivate a farm, can obtain one of his own for nothing" (104). Although the indigenous population remains as invisible here as it does in all of Wakefield's Australian writings, the example of nomadic aboriginality underpins his anxiety about what J. G.A.Pocock describes as the "crucial premiss. . of vagrancy:the premiss that a wandering condition dehumanizes or must precede humanization" (209). Letter from Sydney is haunted by the thought of a settler population devolving to such an uncultured and unsettled state, "without local attachments founded on impressions of the past, without any love of birthplace, without patriotism-unless men constantly roaming over 
immense regions may be called a country" (134). Wakefield's infamous solution of a "sufficient" or minimum price for land sales-debarring the working classes from land ownership and forcing the geographic concentration of the settler population-would prompt Karl Marx's acerbic comment in Capital(1867) that Wakefield's "great merit" as an economist was "to have discovered, not something new about the colonies, but, in the colonies, the truth about capitalist relations in the mother country" (932, original emphases). As a revision of Lockean possessive individualism, however, Wakefield's theory of colonization is distinguished by its reorganization of the diachronic structure of traditional stadial theory into a synchronic relationship, so that the colonial population is able to manifest both the starkly contrasting states of vagrancy and settlement. Crucially, the threat of a settler's reversion to a nomadic state does not arise from the proximity of an indigenous population, but from the temptations of primitive accumulation available in the apparent nullity of colonial space.

Even as Wakefield's formulaic approach to settler colonization was hotly contested in Britain and across the empire, his ideas and advocacy spurred the creation of colonies in Australia and New Zealand and established the basic economic and social terms by which settlement was understood in the decades prior to the gold rushes. ${ }^{7}$ The expansion of pastoralism in Australia, which was so rapid that the continent supplied almost half of Britain's wool by 1850 (McMichael 101), seemed to conform to stadialist principles: behind the continual expansion of the frontier by squatters, the semi-nomadic pastoralists who dominated the wool trade, "a more intensive process of settlement (largely urban based) proceeded gradually in the settled districts, where 70 percent of the colonial population lived in 1850" (122). The claim that capitalism and culture are equally grounded in a settled population-and the challenge consequently posed to it by the discovery of gold-was accordingly presented with greatest force and clarity in what is generally recognized as the first realist novel written in Australia. Catherine Helen Spence's Clara Morison, set in the continent's only colony founded on explicitly Wakefieldian principles, directly links settler literacy with agricultural production and pits both in opposition to the widespread antisocial behaviors prompted by the gold rushes. The threat of settlement's cultural and economic "eclipse" (Spence 1:218) is focalized through an impoverished but educated emigrant, Clara Morison, whose "journey from governess to domestic servant to genteel wife 
... [is] made possible through an extended marriage plot that hinges on the hero and heroine's shared love of British literature" (Myers 117). Clara falls in love with the refined and gentlemanly Charles Reginald, proprietor of the Taringa sheep station, who shares her tastes and seeks out "the newest works of Dickens, Bulwer, and Thackeray" (1:34). While Reginald clings to his "monotonous and unexciting" pastoralism and the cultured life it sustains (1:49), the outbreak of "gold-fever" gives rise to a Wakefieldian nightmare of dispersion as the colony's male population succumbs to the possibilities of wealth afforded by this new form of primitive accumulation (1:219). Adelaide's streets are "full of a most unsettled-looking population" and "the outskirts . . . are greatly thinned, and the villages round about are almost deserted" (1:222), while in the neighboring colony of Victoria where the gold fields are located, "the universal overturn of society . . is taking place" (2:94). In response, Clara Morison works hard to domesticate these social and economic changes, resettling its male characters after they return dispirited from the diggings and reasserting the alliance of pastoralism, literature, and domesticity through the marriage of Clara and Reginald. The novel concludes "in hopes that the Victoria gold fields will soon yield nothing more than good wages for hard work; so as to offer no very powerful inducement for South Australians to desert their agricultural and mechanical pursuits. Even Victoria is getting into a wonderfully orderly state" (2:272). Simon During has argued that this ending marks Spence's abandonment of "literary terms" for the "political, economic and governmental" (18), yet its alignment of literary cultivation with the cultivation of the soil retraces the intersection of economics and culture articulated by Wakefield's stadial theory of settlement. Published in London in the early years of the gold rushes, however, Clara Morison also marks the impending colonial dissolution of that stadialist consensus: the Lockean narrative of land and labor could no longer be applied to the project of replicating Victorian society in Australia without also reckoning with the forms of sociality emerging on the gold fields.

II.

By late 1852, the effects in Britain of the "fierce, raging lust for gold" had drawn the attention of Household Words: a lead article by George Augustus Sala begins with a single, bravura sentence that spans the entire first column in an attempt to convey the scale of the 
recent population movements. ${ }^{8}$ Commencing with "the wondrous tide of emigration" evident at the London docks, Sala goes on to describe the scene at Southampton of "Hampshire folk . . . departing by whole tribes for the Diggings, with cradle, mattock, and spade" before turning to "Plymouth, and Bristol, and Cork, yea, and the American seaboard far away," ultimately concluding that "verily, all Liverpool seems to be off" (25). Among that decade's "wondrous tide" were a number of writers and artists-including, in addition to Howitt and Horne, the novelist Henry Kingsley; painter William Strutt; and sculptor Thomas Woolner, who prompted Ford Madox Brown's iconic rendering of Victorian emigration, The Last of England (1855) (Serle 353-68)-and several impoverished economists. One of these, W.E.Hearn, had been appointed in 1854 as one of the original professors at the University of Melbourne, an institution established with the "expressed desire that higher education might help to counteract uncivilizing aspects of mounting gold fever" (Goodwin, Economic 568). Hearn's Plutologywas the first work of political economy written in Australia, and alongside Howitt's Land, Labour, and Gold, it registers the disruptive interplay of Greater Britain's material networks, the distinctive conditions of the settler-colonial frontier, and the attempt to map metropolitan forms onto colonial soil and society. While the stadialist conflation of wandering and the primitive was predisposed to a critical view of the gold discoveries and the social disorder they provoked, the colonies' rapid growth directly challenged that developmental narrative and prompted the need to reimagine relationships among the individual, society, and territoriality.

In light of the developmental assumptions of stadialist theory and the expansion of pastoralism that had driven colonial economic growth over the previous decades, the forms of prospecting associated with the early gold rushes seemed to belong to a pre-modern, pre-capitalist state outside any progressive sequence. "Men had left their homes and families, and all the comforts and constraints of civilisation, for a wild life of wandering and seeking," historian David Goodman observes, "It was difficult . . not to think of the activity of gold seeking as regressive, a return to an earlier, less disciplined, and more primitive era" (xvii). Howitt accordingly links the squalid character of the diggings, the powerful desires produced by gold, and the extreme mobility of the digging population-all qualities associated with stadialism's lowest developmental level. What he describes skeptically as "those wonderful diggings which are always floating in the 
imaginations of the digger, and . . drive him on, and on" (1:226) play out in a Wakefieldian spatial and social calamity by producing a "race of diggers" that is "never at rest, and least of all men have they any abiding city" (2:227). Spurred by an irrational desire for enrichment, dependent for success on luck more than discipline, and constantly traversing the landscape, the "wild, nomadic" digger population resembles Australia's maligned indigenous peoples far more than a settled population of British colonists (1:113). Given the stadialist association between literary and agricultural cultivation, it is not surprising that Howitt consistently associates such vagrant mobility with a lack of aesthetic sensibility. Land, Labour, and Gold predictably upholds the beauty of smallholding farms and the "pleasant, if not romantic country" (1:152), and grimly catalogues the squalor of the diggings. But Howitt is most interesting when he acknowledges his own part in such antisocial behaviors. "We have begun to destroy the beauty of this creek," he observes after his party strikes gold along a previously undisturbed section of the Yackandandah Creek: "A little while, and its whole course will exhibit nothing but nakedness, and heaps of gravel and mud. We diggers are horribly destructive of the picturesque" (1:205). Further complicating this and other responses to the gold rushes, however, was the rapid emergence, in close proximity to the primitive Victorian gold fields, of "Marvellous Melbourne" city as a hub of frenetic commercial activity.

The growth of Melbourne appeared to observers to be as contrary to the pastoral norms of a settled society as the gold diggings themselves. Henry Kingsley's invocation of Melbourne in his novel The Recollections of Geoffry Hamlyn (1859) is typical in its account of civilization's explosive emergence from the state of nature. What was two decades ago "the unbroken solitude of a primeval forest, as yet unseen by the eye of a white man" has become "a noble city, with crowded wharves, containing with its suburbs no less than 120,000 inhabitants" (281). The paradox imagined here is that the most modern of imperial cities might be founded on the regression of British settlers to a primitive state. When Howitt turns his attention from the diggings to Melbourne, he finds the diggers' wildly divergent ethnic and national backgrounds and unconstrained appetites writ large in its economic frenzy. The streets are "mottled with the people and costumes of nearly all nations" (1:285), and the diggers' "extravagance of all sorts" is at the center of a widespread speculative mania (1:62): 
The Melbournians, from some cause or other, have shown themselves from the beginning of their brief history, a most mercurial race,-the maddest speculators in the world. . . . They disdain everything but the most lunatic prices and profits. To all warnings, "The gold! the gold!" is the answer, and the assurance that this outrageously unnatural rate of property will last forever.(1:277-78)

For Howitt, the gold rushes presented a problem that could only be solved along the same lines that Spence envisaged-by the settling of Australian society through the widespread establishment of agricultural small-holdings. Yet this conclusion is threatened by Howitt's assertion of an intrinsic relationship between the nomadic sociality of the diggings and the capitalist excesses of Melbourne, precisely because this relationship short-circuits the developmental logic of stadialist history and the rhetoric of settled economic behavior and cultural production that stadialism underpins. Land, Labour, and Gold points to the need for a new vocabulary to describe the settler-colonial project and the perspective that it affords of British society.

In its antipodean reimagining of some of the most fundamental principles of political economy, Hearn's Plutology offers some initial answers to the questions raised in Land, Labour, and Gold about how to comprehend the societal lessons of the gold rushes. Hearn was predisposed to consider the political economy of the gold rushes in less orthodox terms as a result of his training at Trinity College, Dublin, where Richard Whately and Mountifort Longfield had been questioning labor-based definitions of value since the 1830s (Bigelow 11415). The product of Hearn's lectures in the late 1850s and early 1860s, delivered at a university that consisted of "a few buildings in a paddock along the dusty Sydney Road taken by the amateur miners on their way to the diggings" (Moore 39), Plutology is firmly situated in the febrile atmosphere of gold-rush Melbourne. ${ }^{10}$ That colonial context is immediately evident in Hearn's choice of analogies-to take just one example, the vigor of an Australian digger "working on his own account in a payable claim" is contrasted favorably to the sloth of state-employed Italians (43)-but, more fundamentally, Hearn asserts that the settler colony affords a valuable perspective on the discipline of economics because it grants "familiarity with a different state of facts which only residence in a new country still in course of settlement can give" (113). The most immediate outworking of Hearn's localized thinking occurs at the level of form in the "unusual narrative order" of Plutology (Moore 42), which jettisons the orthodoxy of 
stadial theory and the factors of production-land, labor, and gold-in favor of a new, sweeping account of the generative powers of individual consumer appetites.

Plutology offers a sustained argument that society need no longer be thought of as settled in order to imagine the emergence of economic activity and culture. Instead of beginning with a stadialist narrative of the emergence of the laboring Lockean subject, it proffers a biological account of an individual defined by his unpredictable and insatiable appetites. "Not merely is the amount of human desire indefinite," Hearn argues, "but the modes in which desire in many different individuals is manifested, are equally without any practical limit" (18). While the opening sections of Plutology reiterate political economy's familiar investment in differentiating civilization from savagery, their merging of Darwinian theory with utilitarianism leads to the claim that it is not labor, but rather the continued expansion of appetite, that performs the "moral function" of driving the civilizing process:

Our real state of nature consists not in the repression, but in the full development and satisfaction, of all those faculties of which our nature consists. Such a state is found, not in the poverty of the naked savage; but in the wealth of the civilized man. It is the constant and powerful impulse of our varied and insatiable desires, that urges us to avoid the one state, and to tend towards the other. . . . Desires extend themselves with the means of gratification; the horizon is enlarged in proportion as we advance, and each new want, equally accompanied by its pleasure and its pain, becomes a new principle of action. (21)

Hearn's formulation scrambles the most pressing social and cultural connotations of stadialist theory by dissociating unbounded and settled forms of desire from their accustomed levels of civilizational development. The spatialized logic of "proportion," which appears to invoke Wakefield's commitment to an "imaginary standard of elegant proportion" as a guarantor of class structure and values (Merivale 1:84), is now infused with the speculative and irrational behaviors of Melbourne's successful diggers. Consciously abandoning a moralistic stance toward desire, Hearn instead seeks to describe accurately its workings and effects. "We pass no judgment upon the character of the want, or upon the manner in which it should be regulated" (22), he maintains: "We have to deal with them merely as forces, without any other estimate of their characters than the intensity with which they are felt by the persons who experience them" (23). By effectively embracing the unsettled society produced by gold, Hearn offers the 
clearest example of the unfolding settler project's ability to catalyze the revaluation of mid-Victorian narrative models.

\section{III.}

But what of metropolitan culture? After all, Plutology was a "dismal failure" when released in Britain (Moore 45). This question can be approached initially through two brief testaments to Australian gold's global transit. First, R. H. Patterson's The Economy of Capital, or, Gold and Trade (1865) opens in Australia with the discovery of "one of the richest 'placers,' or gold-beds, even of that most auriferous country" (1). Imagining its hazardous excavation and eventual transfer to Britain, Patterson finds the volatile qualities of gold permeating the metropolitan economy and the civilization that it supports: "The City of Gold [i. e. London] is based upon gold: and the foundation is found to be pre-eminently unstable and perilous. . . . It rises and falls, expands and contracts, and sometimes seems to slip away from beneath the City altogether" (168). Second, Mary Elizabeth Braddon's Lady A udley's Secret (1862) commences with George Talboys en route to Liverpool with $£ 20,000$ to his name after three years' labor in the gold fields of Victoria. That colonial fortune will prove surprisingly peripheral to the novel's sensationalist economy, but its relocation nevertheless prefaces a thorough reappraisal of the settled nature of British society and the countryside:

We hear every day of murders committed in the country. . . . sudden and violent deaths by cruel blows, inflicted with a stake cut from some spreading oak, whose very shadow promised-peace. . . . No crime has ever been committed in the worst rookeries about Seven Dials that has not been also done in the face of that sweet rustic calm which still, in spite of all, we look on with a tender, half-mournful yearning, and associate with-peace. (54)

Patterson and Braddon's accounts suggest that by the 1870s, Australian gold was generally available as a trope that licensed the questioning of societal norms. But for metropolitan authors with direct experience of Australia, the settler colony prompted a more thoroughgoing, though still sensationalist, reconsideration of Victorian society. In Jevons's Theory of Political Economy and Trollope's John Caldigate, forms of colonial thinking afforded by Greater Britain play out in accounts of a metropolitan individualism no longer grounded in a specific territory or even the wider nation. 
Jevons arrived in Sydney in 1854 to take up a position as assayer at the new branch of the Royal Mint, and the question of how his five year colonial sojourn might have shaped his subsequent thinking exemplifies the challenge that Greater Britain poses to the nationbased imaginary that has informed Victorian studies. Recent discussions of Jevons's place within Victorian culture by Regenia Gagnier, Catherine Gallagher, and Mary Poovey all skirt his time in Australia, in keeping with a geographically-restricted disciplinary horizon that Caroline Levine attributes to a "logic of autochthony" ("Nation" 649)." The resulting picture of political economy reflects an underlying assumption that colonial experience is incommensurable with forms of thinking undertaken in Britain, but this stands in contrast to an archive that readily encompasses Britain and Australia. Writing prior to his departure from Australia in 1859, Jevons enumerated the "considerable advantages" that had accrued to him in the previous five years, including "a small capital ... [and] my mind wellformed and its direction clearly determined, with a good many years colonial experience of the world which will be equal to doubleas much homeexperience" (Papers 1:110, original emphases). In material terms, Greater Britain's networks of global exchange were at the core of Jevons's work at the Sydney Mint, which facilitated the export of Australian bullion to Britain, as well as the salary he remitted to support his two unmarried sisters in London. He used his ample free time to undertake an extensive reading program in political economy and other social sciences (Schabas 15-19), while also observing the gold fields firsthand. These observations stress the rapid emergence of economic and social order out of inchoate frontier environments: rather than highlighting the vagrancy and disorder one might expect from a stadialist viewpoint, he describes "thousands of very sturdy independent diggers . . rapidly adopting fixed habits, manners, and appearance" (Papers 2:370) and flourishing "mushroom town[s] of canvas thus suddenly created" with "miles of regular canvas streets, densely set with every kind of shop" (2:371). Yet the strongest connection between Jevons's colonial experience and his subsequent metropolitan writing hinges on Hearn's Plutology, which he first praised in an anonymous review in the Spectator. Finding it "in many respects in advance of the treatises of the day, including on certain points even Mr. J. S. Mill's great work," he concluded that "there is something in the development of a colony that nourishes studies of the kind" ("Review" 276). A decade later, in 
the conclusion of his path-breaking The Theory of Political Economy, he would similarly assert, "I have the more pleasure and confidence in putting forward these somewhat heretical views concerning the general problem of economics, inasmuch as they are nearly identical with those arrived at by Professor Hearn, of Melbourne University" (258-59). While not diminishing the significance of other influences on Jevons's thinking, these colonial considerations must nevertheless be reckoned as vital to an economic theory that enables the divergent developmental states of Greater Britain to be embraced within a single ahistorical framework.

Positioning Theory of Political Economy as a response to the material circumstances of settler colonization may seem counterintuitive given its status as a foundational text of the marginal revolution, which directed economics away from social considerations of production and toward abstract mathematical models of consumption. The "relative simplicity" of this approach, Gagnier argues, arises because it is "stripped of epistemological, psychological, and social complexities" (42). Gallagher also offers a deculturated view of Jevons's work, stressing its basis in the universal "biological facts" of bodily sensation (127). Jevons's mathematical turn nevertheless bears a colonial imprint, for it follows Hearn in placing at its center an individual who is defined primarily by the capacity for desire: maintaining that the "general forms of the laws of economics are the same in the case of individuals and nations," Theory of Political Economy posits that society can be construed simply as "multitudes of individuals" (86). This atomized vision remains circumscribed by an implicit racial logic. As Kathleen Frederickson points out, Jevons argues that savages have less temporal awareness than the civilized and, consequently, less willingness to labor and accumulate for long-term purposes; Theory of Political Economy thus remains oriented toward the description of a British economic subject (310). What emerges is a profound challenge to the territorial logic that had underpinned discussions of liberal individualism. Elaine Hadley asserts the "deeply identical" relationship between landed proprietorship and citizenship that persisted into the 1870s and argues that continued imperial expansion posed fundamental questions of "just what grounds of connection . . to civil society and society more generally a liberal individual can establish" (264, original emphasis). The response offered by Jevons's Theory of Political Economy is a deterritorialized British subject who can be 
comprehended across imperial space and who is equally legible in divergent stages of societal development.

Despite Jevons's economic contribution to the imperial project of imagining Greater Britain as a continuous space, gold's unsettling taint persists in his attempts to rationalize political economy as a mathematical science. Furthering Hearn's dismantling of the early Victorian alignment of economics, territory, and labor, Theory of Political Economy offers in its place a statistical account of consumer appetite, equally applicable to metropolitan space and the frontier town of the antipodean gold fields. "We shall never have a science of economics," Jevons maintains, "unless we learn to discern the operation of law even among the most perplexing complications and apparent interruptions"(150). Yet desire remains a persistently unruly presence in this borderless account of the liberal individual, as the fleeting experiences of pleasure and pain at the heart of Jevons's utilitarian calculus ultimately prove impossible to describe or quantify. The stadialist paradox posed by the gold fields-that a civilization might be built by vagrant subjects and their undisciplined appetitesis recapitulated in the central aporia of marginalist thought, whereby a "purely mathematical" economics (78) is claimed to be founded upon the measurement of individual sentiment even though "the numerical expression of quantities of feeling seems to be out of the question" (84). In response to the persistent vagaries of individual desire, Theory of Political Economy proposes a "Fictitious Mean" that will enable their abstraction into a more stable form, in full awareness that such "numerical results ... do not pretend to represent the character of any existing thing" (136). Put another way, Jevons's theory is oriented around a fictional individual whose representative status, as he subsequently explained more fully in The Principles of Science (1874), "enabl[es] us to conceive in a single result a multitude of details" through a "hypothetical simplification of a problem" (363). The installation of this statistical fiction at the center of Victorian political economy marks the transit of the unsettled individual from the Australian colonies to the metropolis, silently naturalizing a settler-colonial hermeneutic as a means for understanding Britain's society and economy.

The imperial vision latent in Jevons's account of fictionalized individual desire is taken up and expanded in the novel, which in Trollope's hands uses such a figure to imagine Britain as coterminous with its 
settler-colonial periphery. Having invested $£ 6,000$ in his son Frederic's 27,000 acre sheep station in New South Wales, Trollope visited Australia for the first time the same year that Theory of Political Economy was published. Yet it was a failure of the traditional pastoral ideal that prompted his return to the continent in 1875, as Frederic was struggling to remain solvent. Despite maintaining that his son's ruin would mean that he could "no longer believe in honesty, industry, and conduct," Trollope ultimately lost most of his money after the sheep station was sold early the following year for only $£ 1,400$ (qtd. in Hall 402). In Australia and New Zealand (1873), the account of his first and more extensive visit, Trollope reflects at length on the gold rushes and their ongoing social impact. While ceding that the sheer labor involved in mining has a "certain redeeming manliness" (1:426), Trollope concurs with previous commentators in his skepticism toward the societal and individual value of gold, a view that is both concentrated and complicated by his attention to the gentrified settler and the gold fields' potential to dissolve class identity. Coming across a digger in Queensland who had attended school with his sons, Trollope reflects,

He had been softly nurtured, well educated, and was a handsome fellow to boot; and there he was eating a nauseous lump of beef out of a greasy frying-pan with his pocket-knife, just in front of the contagious blankets stretched on the ground, which constituted the beds of himself and his companion. It may be that he will strike gold, and make a fortune. I hope so with all my heart. But my strong and repeated advice to all young English gentlemen is to resort to any homely mode of earning their bread in preference to that of seeking gold in Australia. (1:89-90)

Behind Trollope's anxiety regarding the fragility of traditional forms of British culture and society is the recognition of a more fundamental inability to maintain a distinction between gentility and primitive accumulation and speculation. The juxtaposition of such oppositions-gambling and industry, gentility and privation-accords with what Buzard describes as "one of Trollope's signature inconsistencies . . . his deployment of incommensurable rhetorical strategies" ("Portable" 9). In A ustralia and New Zealand, however, the incommensurable terms that cluster around the gentlemanly digger convey a sense that Britishness itself requires redefinition, and that British society might be reread in Australian terms.

This period of intense financial exchange and travel across Greater Britain was bookended by John Caldigate, Trollope's "most wholehearted and accomplished attempt at a sensation novel" 
(Edwards 216), in which Trollope employs Australian gold to explore the inadequacy of the Lockean conception of the individual in the face of a globalized British population. If Australia and New Zealand reluctantly acknowledged British settlers' innate susceptibility to speculation and desire despite their genteel origins, then it is in John Caldigate that these tendencies are fully brought to bear upon metropolitan society. Tracking its gentlemanly protagonist to Australia and back to his family estate in Britain, the novel asserts the surprising compatibility of Australian gold-and the unsettled qualities of character that it foregrounds-with the ancestral connection to land that remained the mythical heart of liberal individualism's political agency. John Caldigate is in many ways a rewriting of the first Palliser novel, Can You Forgive Her? (1865), which was published immediately prior to Frederic's emigration to New South Wales, and the structural differences between the two texts suggest the impact of Trollope's encounters with gold and Greater Britain. The two novels are Trollope's only works set largely in Cambridgeshire, and the sheer ugliness of this location and its associated qualities of stability and sobriety establish it as ground zero for what Paul Delany describes as Trollope's "social myth," the belief that "people are most real and knowable through their ancestral attachment to a tract of land" (765). "Cambridgeshire possesses fewer rural beauties than any other county in England," the earlier text observes, "It is very flat; it is not well timbered; the rivers are merely dikes" (100). The Caldigate estate produces an even more dismal impression: "Folking is not a place having many attractions of its own, beyond the rats. . . . The property is bisected by an immense straight dike . . which is so sluggish, so straight, so ugly, and so deep, as to impress the mind of a stranger with the ideas of suicide" (3-4). The protagonists that emerge from this unspectacular point of origin, both named John, embody markedly different forms of gentlemanly character. In Can You Forgive Her?, the drably-named John Grey lives a settled life amidst the "desolate calmness" of his country house, eschewing London society and politics to spend time in his library and cultivate his extensive gardens (111). By contrast, the likeable but undisciplined John Caldigate gets into debt at Cambridge; excited by news of the gold discoveries in Australia, he subsequently emigrates in the hope of redeeming his fortunes. Whereas Grey doggedly pursues his erstwhile fiancée across Europe, Caldigate is still en route to Sydney when he abandons his 
understanding with the beautiful Hester Bolton to become engaged to an actress, Euphemia Smith. When Caldigate returns to Britain as a wealthy man and marries Hester, Euphemia arrives to accuse him of bigamy, leading to his trial and conviction. These global movements of characters and capital explicitly thematize Britain's imbrication in Greater Britain, as the Caldigate estate and title are simultaneously strengthened and threatened by Australian gold.

In Australia and New Zealand, Trollope casts gold as a seductive and socially disruptive force and characterizes the quest for it as an irrational, speculative behavior contrary to the tenets of civil society. The possibility of primitive accumulation creates a "fury in the minds of men compelling them to search for it, let the risk, the danger, the misery, the probable losses, be what they may," as the thought of such "haphazard" mineral wealth "overcomes the imagination of the unconscious thinker, and takes possession of his heart and brain" (1:283). The translation of these sentiments into John Caldigate is enabled by the formal vocabulary of the romance, which Trollope typically invokes in his fiction to demarcate attitudes and territories that lie outside the norms of bourgeois sociality (Kendrick 62-82). Australian gold is accordingly figured as "an article which adds fervour to the imagination and almost creates a power for romance" (Trollope, John 106), capable of overwhelming rationality and selfdiscipline: "There is a curse about it, or a blessing,-it is hard to decide which-that makes it almost impossible for a man to tear himself away from its pursuit when it is coming in freely" (122). Surprisingly, given his scapegrace past, Caldigate seems impervious to this temptation. Rising from the ranks of the vagrant gold diggers to part-owner of a profitable mine, he sells out and returns to Britain, where he is able to repurchase the entail on the family estate and renew his relationship with his father; he soon marries Hester and fathers a son, assuring the family succession and the continuation of tradition. Yet at the same time as this act of reverse migration brings Britain and Australia into closer alignment, Trollope employs another form of narrative desireerotic romance-to disrupt metropolitan society and its expectations of gentlemanly character.

Caldigate's relationship with Euphemia Smith, which drives Trollope's sensationalist plot, seems at first incommensurable with his disciplined success as a miner; yet his wayward passion is entirely in keeping with the unsettled ethos of appetite and desire that defines 
the gold fields. His susceptibility to romance is cast as a failure of character-"he . . . was, within his own mind, conscious of his lack of all purpose, and very conscious of his folly" (66)-but the novel does not suggest that Caldigate has simply been degraded by his exposure to a colonial zone of primitive accumulation. In contrast to accounts of Trollope's attitude toward the empire that stress his commitment to asserting the coherence and stability of English racial identity, John Caldigate instead suggests that this environment reveals the latent volatility of the mode of gentlemanly character he embodies. Buzard highlights the image offered in Australia and New Zealand of Greater Britain as "an inescapable England repeated all round the world," so that "nowhere the Englishman goes will he not encounter the image of his English self" ("Portable" 15), yet John Caldigate instead employs the settler colony to trouble that sense of identity. Drawing on the vocabulary of desire and chance that animates Howitt and Jevons's responses to the gold fields, the novel foregrounds the contingency inherent to class and racial identity. Reflecting on the contrasting fates of himself and his fellow-migrant, the alcoholic Dick Shand, Caldigate comes to believe that his success is due to luck rather than character:

I am sometimes aghast with myself when I think of the small matter which, like the point on a railway, sent me running rapidly on to prosperity,-while the same point, turned wrong, hurried him to ruin. . . . It was something nature did for me rather than virtue. I am a rich man, and he is a shepherd, because something was put into my stomach capable of digesting bad brandy, which was not put into his. (136)

That is, instead of reaffirming the stability and global translatability of British identity by aligning it with inherent values of gentility, the novel attributes Caldigate's social and financial success to individual circumstances as random as striking gold.

"I am the least settled man in all the world" (143), Caldigate claims upon his return from Australia. Spoken in response to the maneuverings of a prospective mother-in-law, his words also reflect the novel's troubling of the Lockean equation of territory and civic identity. The ostensibly settled world of Cambridgeshire is sensationally disrupted by Euphemia's accusation of bigamy and Caldigate's subsequent trial and conviction, with the salacious details of his life on the gold fields adding to the "romance of the occasion" (398). His conviction and the consequent delegitimation of his son suggest that the social disorder of the gold fields and the bullion extracted there are equally 
antithetical to British society, although the metropolitan status quo is seemingly restored when new evidence leads to a Queen's pardon. Yet the novel's refusal to fully disavow the settler colony is signaled by the striking contrast between the fate of Caldigate's gold and that of the gold in the archetypal Victorian narrative of scandalous Australian wealth, Great Expectations (1861). In Dickens's novel, the introduction of Magwitch's money into British society immediately produces social upheaval, and Pip's eventual refusal of the convict's wealth signifies an affective resistance to the colonial supplementation of metropolitan life. By contrast, Caldigate's wealth not only remains untouched throughout the course of the novel, but he also acknowledges that his English home is inextricably linked to the settler colony: "I should not have done very well here unless I had been able to top-dress the English acres with a little Australian gold" (217). Caldigate's unapologetic stance caught the eye of the Saturday Review, which complained that Trollope "so far excuses him under the circumstances that . . . he never inflicts on him the novelist's true punishment-the disapproval of the honest conscientious characters of the story" (qtd. in Smalley 456). The ongoing continuities between Cambridgeshire and Australia are further underscored by the fact that his pardon does not actually erase the original conviction, as is spelled out to him in a letter from the Home Office: "We have but this lame way of redressing a great grievance. I am happy to think that in this case the future effect will be as complete as though the verdict had been reversed" (587). With the original bigamy conviction remaining a ghostly presence in the novel, its happy ending ultimately remains dependent upon the legal classification of Caldigate's Australian romance rather than its absolute disavowal.

Caldigate's limited yet successful reintegration within British society occurs on the back of the novel's assimilation of the colonial romance with the realism of the provincial novel, a formal rapprochement that signals the interpenetration of the disparate spaces of Greater Britain. In keeping with these expanded horizons, John Caldigate's dissolution of the intrinsic relationship between territoriality and its protagonist's character leads, by the concluding chapter, to an ongoing traffic between Britain and the settler colonies. The minor civil servant in the Post Office whose detective work uncovered the fraudulent nature of Euphemia Smith's evidence is temporarily posted to New South Wales, ostensibly to reform the Sydney 
office. Instead, he facilitates a minor act of colonial knowledge transfer when he "bring[s] home with him . . . a newly-discovered manner of tying mail-bags" (611). At the same time, while the dissolute Dick Shand remains unfit for metropolitan society, he is able to participate in the imperial economy after Caldigate provides him with the capital to buy into a Queensland sugar company, ensuring the continued circulation of Australia's gold within Greater Britain. Paradoxically, the sheer normality with which these continuing colonial exchanges are portrayed is ultimately one of the novel's most striking features.

IV.

The reformulation of British identity and its relationship to land and labor prompted by the Australian gold rushes coincided with movements toward the deterritorialization of liberalism and liberal subjectivity simultaneously occurring in other colonial contexts. Hadley argues that debates about Irish tenancy and the codification of occupancy as the basis of rights in the Irish Land Act of 1870 produced an emergent sense of "landed localism," instantiating a liberal nationalism that "problematizes the universalism of the liberal subject and its capacity to relocate its 'connection' beyond national boundaries" (287). Along similar lines, Andrew Sartori maintains that discussions over tenancy and custom in Bengal meshed with those concerning Ireland to form a "crucial field in which metropolitan intellectuals could work out their own anxieties about the status of property as a normative foundation of liberal polity" (29). Charting the colonial and metropolitan responses to the Australian gold rushes brings to light a different liberal dynamic: the emergence of an ideological terrain capable of sustaining the idea of Greater Britain as a racially homogeneous, worldwide political formation that came to public prominence from the 1870s onward. Duncan Bell's history of the movement for imperial federation stresses its dependence on a distributed notion of British identity and concomitant reimagination of metropolitan space in global terms. As Bell observes, J. R. Seeley's The Expansion of England (1883) made explicit the "shift in political-as well as spatiotemporalconsciousness" that was seen as a necessary precursor to any closer imperial connection: "The first and most important step on the road to building Greater Britain was a cognitive one, involving a transformation in the way that people imagined the empire. 'If Greater Britain 
in the full sense of the phrase really existed,' insisted Seeley, 'Canada and Australia would be to us as Kent and Cornwall”' (Idea 9). Seeley's formulation illuminates the new political efficacy of imagining the coevalness of metropolitan and settler colonial spaces, and highlights this vision's dependence on the production of patriotic and racial sentiments capable of traversing imperial space.

At the same time, Seeley's positioning of the colonies in provincial terms contrasts with the colonial origins of Trollope and Jevons's attempts to imagine the translatability of a recognizably British subject across imperial space. In this light, John Caldigate stages a kind of imperial thinking different from that of the period's most prominent manifestos for the geopolitical revaluation of the merits of the settler empire, C. W. Dilke's Greater Britain (1868) and J. A. Froude's Oceana (1886). These works are also organized around an individualized and geographically mobile narrative perspective, a choice that enables Dilke and Froude to present their personal journeys through the settler empire as metonymies for the imperial sentiments and related political innovations they were seeking to describe and advance. ${ }^{12}$ Yet both Dilke and Froude break off their narratives at the points of their return by steamship to Britain, reasserting the primacy of metropolitan space in a manner that anticipates the asymmetric understanding of portability animating current criticism. In contrast, the gold-inflected accounts of empire offered by Trollope and Jevons stand out for their willingness to reimagine metropolitan space and subjectivity in colonial terms: these works' revaluations of the civilizing power attributed to land and labor-prompted by the dramatic events in Australia-helped bridge Greater Britain in new ways by reconceiving the modern British individual as a powerfully mobile yet unpredictably volatile property. In closing an empire-wide circuit of representational exchange that commenced with Wakefield's impersonation of a settler in Letter from Sydney, they also suggest a broader need to rethink the place of the settler colony within Victorian studies: rather than simply offering a destination for metropolitan representations, it comes into focus as a vital and active player in the ongoing reconfiguration of metropolitan narrative forms and the re-imagination of liberal subjectivity.

Massey University 


\section{NOTES}

I thank Nathan K. Hensley, Timothy Alborn, Duncan Bell, Ivan Kreilkamp, and the anonymous Victorian Studies readers for their advice on earlier versions of this article. The research and writing of this article was supported by the Marsden Fund Council, administered by the Royal Society of New Zealand.

1. The imperial portability of metropolitan culture is also central to Myers 1-16. For an alternative account of Victorian realism as a "defensive" response to imperial expansion, see Buzard, Disorienting 43.

2. Bell points out that, "From the mid-nineteenth century onwards, the normative and legal distinction between settler colonies and the rest of the empire was inscribed ever more deeply into the elite British political imagination" (Reordering 38).

3. Although "Greater Britain" was sometimes used to describe the entire empire or the global Anglo-Saxon population (including the United States), this essay employs the term in accordance with its "most frequent usage" to signify the settler colonies in particular (Bell, Idea 7). For criticism employing these alternative definitions, see Plotz 46-50 and Lecourt.

4. While similarly epochal discoveries in California directly preceded the Australian gold rushes, and there was considerable movement between the two frontiers, here I argue that the later discoveries had a distinct intellectual impact on Victorian culture because they occurred within the ambit of empire: "Suddenly, Britain had her own Eldorado. British colonies would now feel the golden spur of economic development; gold-seeking British emigrants could now travel to a British destination; the proceeds of the prospectors and miners would now flow directly into the imperial economy" (Stafford 216). For comparative accounts of the Californian and Australian gold rushes, see Belich 306-30 and Goodman 1-45.

5. Wakefield's broader critique of Ricardian economic orthodoxy hinged on the argument that the British economy was not capable of fully absorbing its available capital, and that the export of capital through colonization would enhance rather than diminish the national economy. See Winch.

6. For the origin, publication, and reception of Letterfrom Sydney, see Ballantyne.

7. For instance, although Merivale's influential Lectures on Colonization and Colonies (1842) are in large part devoted to debunking Wakefield's theory, they nevertheless wax lyrical over "its simplicity, its facility of adaptation, its high practical utility" (1:85-86).

8. During 1852, the colony of Victoria received almost 44,000 emigrants from the United Kingdom, and more than 250,000 arrived from there during the period 1852-61 (Serle 385).

9. In contrast to the more organized and capital-intensive mining operations that would later be required to exploit less-accessible forms of ore, the alluvial deposits that triggered the initial gold rushes were readily located by individual prospectors and were accessible to diggers with minimal equipment-requiring "neither skill nor capital, but only strength and health" (Stafford 224).

10. For a broader account of the emergence of Melbourne's literary culture in the 1850s, see Rudy.

11. See Gagnier 19-60, Gallagher 118-55, and Poovey 219-83. Economic historians have sporadically attempted to assess the long-term significance of Jevons's time in 
Australia, although their emphasis on his reading differs from my account of the generative nature of the social environment. See, for example, White.

12. For the "world-making" intent of Dilke’s Greater Britain, see Johnston 33.

\section{WORKS CITED}

Ballantyne, Tony. "Remaking the Empire from Newgate: Wakefield's A Letter from Sydney." Ten Books that Shaped the British Empire: Creating an Imperial Commons. Eds. Antoinette M. Burton and Isabel Hofmeyr. Durham: Duke UP, 2014. $29-49$.

Belich, James. Replenishing the Earth: The Settler Revolution and the Rise of the AngloWorld, 1783-1939. Oxford: Oxford UP, 2009.

Bell, Duncan. The Idea of Greater Britain: Empire and the Future of World Order, 1860-1900. Princeton: Princeton UP, 2007.

—. Reordering the World: Essays on Liberalism and Empire. Princeton: Princeton UP, 2016.

Bigelow, Gordon. Fiction, Famine, and the Rise of Economics in Victorian Britain and Ireland. Cambridge: Cambridge UP, 2003.

Braddon, Mary Elizabeth. Lady Audley's Secret. Ed. David Skilton. Oxford: Oxford UP, 1987.

Bridge, Carl, and Kent Fedorowich. "Mapping the British World." The British World:Diaspora, Culture and Identity. Eds. Bridge and Fedorowich. London: Cass, 2003. 1-15.

Buzard, James. Disorienting Fiction: The Autoethnographic Work of Nineteenth-Century British Novels. Princeton: Princeton UP, 2005.

— . "Portable Boundaries: Trollope, Race, and Travel." Nineteenth-Century Contexts 32.1 (2010): 5-18.

Darwin, John. The Empire Project: The Rise and Fall of the British World-System, 1830-1970. Cambridge: Cambridge UP, 2009.

Delany, Paul. "Land, Money, and the Jews in the Later Trollope." Studies in English Literature 32.4(1992): 765-87.

During, Simon. "Out of England: Literary Subjectivity in the Australian Colonies, 17881867." Imagining A ustralia:Literature and Culture in the New New World.Eds.Judith Ryan and Chris Wallace-Crabbe. Cambridge: Harvard UP, 2004. 3-21.

Edwards, P. D. Anthony Trollope, His A rt and Scope. Hassocks: Harvester, 1978.

Fowler, Frank. Southern Lights and Shadows: Being Brief Notes of Three Years'Experience of Social, Literary, and Political Life in A ustralia. London: Sampson, 1859.

Frederickson, Kathleen. "Liberalism and the Time of Instinct." Victorian Studies 49.2 (2007): 302-12.

Gagnier, Regenia. The Insatiability of Human Wants: Economics and Aesthetics in Market Society. Chicago: U of Chicago P, 2000.

Gallagher, Catherine. The Body Economic: Life, Death, and Sensation in Political Economy and the Victorian Novel.Princeton:Princeton UP, 2005.

"Gold-Seeking at Home." Chambers's Edinburgh Journal 24 Jul. 1852: 60-63.

Goodman, David. Gold Seeking: Victoria and California in the 1850s. St Leonards: Allen, 1994.

Goodwin, Craufurd D. W. "British Economists and Australian Gold." The Journal of Economic History 30.2 (1970): 405-26.

—.Economic Enquiry in A ustralia. Durham: Duke UP, 1966.

Hadley, Elaine. Living Liberalism:Practical Citizenshipin Mid-Victorian Britain. Chicago: U of Chicago P, 2010.

Hall, N.John. Trollope: A Biography. Oxford: Clarendon, 1991. 
Hearn, William Edward. Plutology: or, The Theory of the Efforts to Satisfy Human Wants. London: Macmillan, 1864.

Hickford, Mark. Lords of the Land:Indigenous Property Rights and the Jurisprudence of Empire. Oxford: Oxford UP, 2011.

Hofmeyr, Isabel. The Portable Bunyan: A Transnational History of The Pilgrim's Progress. Princeton: Princeton UP, 2004.

Horne, R. H. Australian Facts and Prospects: To Which is Prefixed the Author's Australian Autobiography. London: Smith, 1859.

Howitt, William. Land, Labour, and Gold; or, Two Years in Victoria: With Visits to Sydneyand Van Diemen's Land. 2 vols. London: Longman, 1855.

Jevons, William Stanley. Papers and Correspondence of William Stanley Jevons. Eds. R. D. Collison Black and Rosamond Könekamp. 7 vols. London: Macmillan, 1972-81.

—. The Principles of Science: A Treatise on Logic and Scientific Method. London: Macmillan, 1913.

. "Review of Plutology; or, the Theory of the Efforts to Satisfy Human Wants." Spectator 5 Mar. 1864: 276.

- The Theory of Political Economy. Ed. R. D. Collison Black. Harmondsworth: Penguin, 1970.

Johnston, Anna. “Greater Britain': Late Imperial Travel Writing and the Settler Colonies." Oceania and the Victorian Imagination: Where All Things Are Possible. Eds. Richard D. Fulton and Peter H. Hoffenberg. Farnham: Ashgate, 2013.31-44.

Kendrick, Walter M. The Novel-Machine: The Theory and Fiction of A nthony Trollope. Baltimore:Johns Hopkins UP, 1980.

Kingsley, Henry. The Recollections of Geoffry Hamlyn. Eds. Paul Eggert, J. S. D. Mellick, and Patrick Morgan. St. Lucia: U of Queensland P, 1996.

Lecourt, Sebastian. "The Mormons, the Victorians, and the Idea of Greater Britain." Victorian Studies 56.1(2013): 85-111.

Levine, Caroline. "From Nation to Network." Victorian Studies55.4 (2013): 647-66.

—. "Strategic Formalism: Toward a New Method in Cultural Studies." Victorian Studies 48.4 (2006): 625-57.

McCulloch,J. R. The Principles of Political Economy; With a Sketch of the Rise and Progress of the Science. London: Tait, 1830.

McMichael, Philip. Settlers and the Agrarian Question: Foundations of Capitalism in Colonial A ustralia. Cambridge: Cambridge UP, 1984.

Magee, Gary Bryan, and Andrew S. Thompson. Empire and Globalisation: Networks of People, Goods and Capital in the British World, c. 1850-1914. Cambridge: Cambridge UP, 2010.

Marx, Karl. Capital: A Critique of Political Economy. Trans. Ben Fowkes. Ed. Ernest Mandel. London: Penguin, 1976.

Merivale, Herman. Lectures on Colonization and Colonies. 2 vols. London: Longman, 1842.

Moore, Gregory C. G. “The Anglo-Irish Context for William Edward Hearn's Economic Beliefs and the Ultimate Failure of His Plutology." European Journal of the History of Economic Thought18.1(2011):19-54.

Myers, Janet C. Antipodal England: Emigration and Portable Domesticity in the Victorian Imagination. Albany: State U of New York P, 2009.

Patterson, R. H. The Economy of Capital, or, Gold and Trade. Edinburgh: Blackwood, 1865. Plotz,John. Portable Property: Victorian Culture on the Move.Princeton:Princeton UP, 2008. Pocock, J. G. A. “Tangata Whenua and Enlightenment Anthropology.” The Discovery of 
Islands: Essays in British History. Cambridge: Cambridge UP, 2005. 199-225.

Poovey, Mary. Genres of the Credit Economy:Mediating Value in Eighteenth-and NineteenthCentury Britain. Chicago: U of Chicago P, 2008.

Rudy,JasonR. “OnLiterary Melbourne:Poetry in theColony,ca.1854." BRANCH:Britain, Representation and Nineteenth-Century History. Ed. Dino Franco Felluga. Jul. 2012. $<$ http://www.branchcollective.org/?ps_articles=jason-r-rudy-on-literary -melbourne-poetry-in-the-colony-ca-1854>.

Sala, George Augustus. "Cheerily, Cheerily!" Household Words 25 Sep. 1852: 25-31.

Sartori, Andrew. Liberalism in Empire: An Alternative History. Oakland: U of California $\mathrm{P}, 2014$.

Schabas, Margaret. A World Ruled by Number: William Stanley Jevons and the Rise of Mathematical Economics. Princeton: Princeton UP, 1990.

Serle, Geoffrey. The Golden Age: A History of the Colony of Victoria, 1851-1861. Carlton: Melbourne UP, 1977.

Smalley, Donald Arthur, ed. Trollope: The Critical Heritage. London: Routledge, 1969.

Spence, Catherine Helen. Clara Morison: A Tale of South A ustralia During the Gold Fever. 2 vols. London: Parker, 1854.

Stafford, Robert A. "Preventing the 'Curse of California': Advice for English Emigrants to the Australian Goldfields." Historical Records of Australian Science 7.3 (1988): 215-30.

Trollope, Anthony. A ustralia and New Zealand. 2 vols. London: Chapman, 1873.

—. Can You Forgive Her? Oxford: Oxford UP, 1973. .John Caldigate. Ed. N.John Hall. Oxford: Oxford UP, 1993.

Wahrman, Dror. "The Meaning of the Nineteenth Century: Reflections on James Belich's Replenishing the Earth." Victorian Studies 53.1 (2010): 91-99.

Wakefield, Edward Gibbon. A Letter from Sydney: The Principal Town of A ustralasia. The Collected Works of Edward Gibbon Wakefield. Ed. M. F. Lloyd Prichard. Glasgow: Collins, 1968. 93-185.

White, Michael V.“Jevons in Australia:A Reassessment." Economic Record58.1(1982):32-45.

Winch, Donald N. "Classical Economics and the Case for Colonization." Economica 30.120 (1963): 387-99. 